\title{
Toxic substances in hearts of children with cardiovascular malformations
}

\author{
O Koval ${ }^{1 *}$, I Mokryk², N Nagorna', G Dubova'', O Bordyugova'', A Novack², O Pshenychnaya', R Klymanskiy², \\ O Kartashova ${ }^{2}$, V Konov ${ }^{2}$
}

From 23rd World Congress of the World Society of Cardio-Thoracic Surgeons

Split, Croatia. 12-15 September 2013

\section{Background}

According to experimental data, numerous substances (including toxic, potentially toxic, conditionally essential chemical elements) have ability to pass through the placental barrier and disrupt cardiogenesis. The aim of this research was to study the level of toxic substances content in heart tissue samples of children with CHD.

\section{Methods}

29 children (17 boys and 12 girls), aged from 14 days to 17 years old with different CHD underwent content analysis of following toxic substances: $\mathrm{Al}, \mathrm{Cd}, \mathrm{Pb}, \mathrm{Hg}$, $\mathrm{Be}, \mathrm{Ba}, \mathrm{Tl}, \mathrm{Bi}, \mathrm{As}, \mathrm{Ni}, \mathrm{Sb}, \mathrm{Sn}, \mathrm{Sr}, \mathrm{Ti}, \mathrm{W}, \mathrm{Zr}, \mathrm{Ag}, \mathrm{Li}, \mathrm{B}$, $\mathrm{Co}, \mathrm{Si}, \mathrm{V}$ in intraoperative (23) and autopsy (6) biopsy tissue samples of heart $(n=37)$ and great vessels $(n=18)$ by atomic emission and absorption spectrometry methods in inductively coupled plasma. Study received an approval of ethic committee of the clinic.

\section{Results}

Excess of permissible level of six toxic elements was revealed in myocardium, endocardium, pericardium and aortic wall tissue samples of $79.3 \%(n=23)$ of patients. Excess of permissible toxic barium content had $72.4 \%$ of patients; conditionally essential lithium content $-20.7 \%$; toxic aluminum content $-17.2 \%$; potentially toxic nickel content $-6.8 \%$; strontium and arsenic content $-3.5 \%$. Excess rate of these elements ranged from two to ten or more times and depended on biopsy points. Namely, in aortic coarctation, valve atresia, septal defect areas their level was higher than in normal areas of heart or great vessel.

\footnotetext{
* Correspondence: aleksandrakoval@ya.ru

${ }^{1}$ Pediatric Subdepartment of Internship and Postgraduate Education Faculty of Donetsk National Medical University n.a. M. Gorkiy, Donetsk, Ukraine Full list of author information is available at the end of the article
}

\section{Conclusions}

Our results indicate that, children with CHD have a special elevated set of specific toxic substances at the site of malformation. The above mentioned suggests a possible role of barium, aluminum, lithium, nickel, strontium, arsenic in formation of cardiovascular malformations, that needs further evaluation.

\section{Authors' details}

${ }^{1}$ Pediatric Subdepartment of Internship and Postgraduate Education Faculty of Donetsk National Medical University n.a. M. Gorkiy, Donetsk, Ukraine. ${ }^{2}$ Department of Cardiosurgery, Cardiology and Rehabilitation for Children, Government Institution "Institute of Urgent and Recovery Surgery named after V. K. Gusak National Academy of Medical Science of Ukraine", Donetsk, Ukraine.

Published: 11 September 2013

doi:10.1186/1749-8090-8-S1-0139

Cite this article as: Koval et al:: Toxic substances in hearts of children with cardiovascular malformations. Journal of Cardiothoracic Surgery 2013 8(Suppl 1):0139.

Submit your next manuscript to BioMed Central and take full advantage of:

- Convenient online submission

- Thorough peer review

- No space constraints or color figure charges

- Immediate publication on acceptance

- Inclusion in PubMed, CAS, Scopus and Google Scholar

- Research which is freely available for redistribution

\section{() Biomed Central}

